Anna Mojsiewicz

Uniwersytet Gdański

\title{
Obcy jako Inny: różne oblicza obcego w literaturze science fiction
}

Inny przeraża i fascynuje, przekracza granice, których Ja nie odważy się przekroczyć bądź nawet ich nie dostrzega. W końcu Inny niezmiennie kryje się również we Mnie. Inny towarzyszy człowiekowi od zawsze, a pomimo tego skutecznie wymyka się próbom zdefiniowania i zrozumienia. Tę szczególną pozycję Innego określa Edmund Husserl, pisząc, że Inny jest dostępny wyłącznie w swojej niedostępności, sytuuje się tym samym w atopii, czyli nie-miejscu, do którego Ja nie ma i nie może mieć dostępu (Waldenfels 2002). Literatura science fiction czerpie inspirację z tej niezwykłej zależności i wyposaża postać kosmity w cechy Innego. Obcy w fantastyce naukowej przyjmuje wiele obliczy.

Analizując pojęcie nieznajomego czy przybysza, Bernhard Waldenfels dokonuje kategoryzacji obcości. Wyodrębnia obcość codzienną doświadczaną przez nas na przykład w stosunku do sąsiadów. Istnieje między nami pewna nieprzekraczalna bariera, która wyznacza granice ogniska domowego, a tym samym broni prywatności. Mój sąsiad, przechodzień na ulicy czy odgrodzony ladą sklepową sprzedawca jednak nie burzą mojego swojskiego świata, nie zagrażają jego strukturze, ponieważ sami się w nią wpisują. Kolejną kategorią jest obcość strukturalna, której doświadczamy w spotkaniu z odmiennością kulturową. Wreszcie Waldenfels wyodrębnia obcość radykalną:

Dotyczy ona wszystkiego, co pozostaje poza wszelkim porządkiem i stawia nas wobec wydarzeń, które podają w wątpliwość nie tylko jakąś określoną interpretację, lecz samą „możliwość interpretacji”. [...] To, co obce radykalnie, da się ująć tylko jako nadwyżka, wybryk przekraczający istniejący horyzont sensu (Waldenfels 2002: 34-35).

W poniższym artykule pragnę prześledzić sposób, w jaki science fiction wykorzystuje obcego, aby mówić o problemach ontologicznych - związanych z próbą zdefiniowania człowieczeństwa - etycznych - towarzyszących reakcji na to, co Inne - a także epistemologicznych, które łączą się z pytaniem, czy w ogóle możliwe jest zrozumienie Innego. Omawiając te zagadnienia, posłużę się trzema przykładami kreacji obcego: w Robocie (1973) Adama Wiśniewskiego-Snerga, Mówcy umartych (1986) Orsona Scotta Carda i Solaris (1961) Stanisława Lema. Zaprezentuję funkcje, które postacie obcych pełnią w wymienionych książkach. 
Waldenfels zauważa, że Swojskość nie może istnieć bez Obcości, ponieważ aby określić granice Swojskości, potrzebne jest również Obce i Inne, które będziemy mogli usytuować w przestrzeni „poza”. Można więc powiedzieć, że Swojskość kreuje się przez zetknięcie z Obcością. W analogiczny sposób Waldenfels odnosi się do Freudowskiego pojęcia identyfikacji:

[...] staję się sobą dzięki temu, iż odnoszę się do innych. Staję się tym, czym jestem, ponieważ utożsamiam się z cząstką rodziców, z przodkami, z grupą, z social self $\mathrm{w}$ sensie Williama Jamesa. [...] za obce uchodzi to, co wykluczone jest $z$ kolektywnej sfery własnego i oddzielone od kolektywnej egzystencji, czego więc nie dzieli się z innymi. Obcość w tym sensie oznacza brak przynależności do pewnego „my” (Waldenfels 2002: 17-18).

Pamiętając o tych zależnościach, przyjrzyjmy się głównemu bohaterowi i narratorowi Robota, robotowi o nazwie BER-66. Protagonista Snerga jest skonstruowanym przez obcą rasę robotem, który przemierzając porwane przez tajemnicze Nadistoty schron oraz miasto Kaula-Sud, poszukuje definicji i drogi do człowieczeństwa. Historia tego zbudowanego na zasadzie antytezy bohatera - robota poszukującego w sobie człowieczeństwa - zmusza do refleksji nad definicją człowieka, granicą między tym, co swojskie i ludzkie, a tym, co obce i nieludzkie, wreszcie nad tym, co czyni nas ludźmi. Postać robota, jak i trzewia Mechanizmu, w którym został skonstruowany, są zbudowane za pomocą obrazowania opartego na grze przeciwieństw i niespodziewanych podobieństw między tym, co naturalne, autentyczne, a tym, co mechaniczne i wtórne. Nagromadzenie epitetów powiązanych ze światem organicznym w opisie wnętrza Mechanizmu sprawia, że taśma produkcyjna, po której suną kolejne egzemplarze robotów podobnych do BERa-66, jak on opatrzonych odpowiednimi numerami seryjnymi zamiast imion, rzeczywiście przypomina - co słusznie zauważa Rafał Nawrocki - układ rozrodczy kobiety. Przetransportowanie bohatera z wnętrza Mechanizmu do schronu pod Kaula-Sud poprzedza kilkumiesięczny pobyt w odosobnionej, ciemnej komorze - okres adaptacji i przystosowania BERa-66 do życia w ludzkim społeczeństwie. Ponadto linia produkcyjna, po której posuwa sie przezroczysty cylinder BERa-66, jest tunelem zakończonym ciasnym, prowadzącym w górę szybem stamtąd bohater zostaje dosłownie wtłoczony do świata zewnętrznego (Nawrocki 2011).

Powołując się na obserwacje George'a Simmela i Maxa Webera, Richard Lehan w książce The City in Literature: An Intellectual and Cultural History zauważa, że lęk przed zbytecznością czy też brakiem znaczenia oraz anonimowością życia ludzkiego nieustannie towarzyszą nowożytnemu człowiekowi (Lehan 1998). Sytuacja BERa-66 wydaje się ilustracją tego strachu przed zagubieniem wśród masy: istoty wykreowane przez Mechanizm nie rodzą się, ale są produkowane; nie mają imion, a jedynie numery seryjne. Produkty Mechanizmu jednakże żyją jak ludzie, doświadczają ludzkich doznań, a nawet (przynajmniej jeden szczególny egzemplarz) odczuwają wątpliwości co do celu istnienia i własnej tożsamości. Jak odnotowuje Scott Sanders, wyżej wspomniany lęk jest wyrażony w powojennym science fiction przez zatarcie granicy między człowiekiem a maszyną: człowiek może być sterowany, maszyna może myśleć (Nawrocki 2011). 
Przywołany fragment stanowi zaledwie początek wędrówki BERa-66 przez kompleks miasta Kaula-Sud oraz rozciągający się pod nim rozległy schron. Zagadkowy świat, w który BER-66 zostaje rzucony, prowadzi do całkowitej alienacji bohatera. Nie tylko nie rozumie zasad panujących w bunkrze oraz nie potrafi ogarnąć rozumem fantastycznych zjawisk, których jest świadkiem, ale też nie może zwierzyć się nikomu ze swoich wątpliwości i obserwacji. Jest obcym, przynajmniej teoretycznie zagrażającym społeczności schronu. Tym bardziej groźba dekonspiracji wymusza na nim niezwykłą czujność i poskromienie wrodzonej ciekawości. Wladenfels zapytuje, od czego zaczyna się obcość? Czy rodzi się ona w moim postrzeganiu siebie jako obcego wobec innych, czy też innych jako obcych w stosunku do mnie? „Rozstrzygnięcie zależy od tego, gdzie umieścimy miarę normalności, czy w świecie własnym, czy też w świecie innych" (Waldenfels 2002: 41). Położenie BERa-66 sugerowałaby pierwszy przypadek; w końcu jest szpiegiem na usługach Mechanizmu i Nadistot, które porwały miasto Kaula-Sud z powierzchni Ziemi. Niemniej sytuacja niebawem ulega zmianie.

Herbert George Wells w Mind at the End of Its Tether wyraża pesymistyczny pogląd, że gatunek ludzki osiągnął swój kres (Lehan 1998). W świecie Robota jego teza ma nie tylko wymiar symboliczny, ale nabiera realnego kształtu, kiedy BER-66 odkrywa, że mieszkańców schronu stopniowo zastępuje się robotami podobnymi do niego. Mechanizacja człowieka, a co za tym idzie - unicestwienie podmiotowości jednostki dokonują się w pełni. Lęk przed zatraceniem człowieczeństwa w obliczu zagubienia w ponowoczesnym molochu lub ugięcia się przed opresyjnym systemem przybiera konkretną formę: oto ludzie są zastępowani przez maszyny tak dalece ich przypominające, że niemożliwe odróżnienie jednych od drugich staje się niemożliwe. Rzeczywistość rozpada się, ustępując miejsca Baudrillardowskiemu symulakrum.

Jest to również krytyczny moment dla samego bohatera, który postanawia zbuntować się przeciwko Mechanizmowi, niezależnie od tego, czy jest jego wadliwym produktem, czy też jednym z ostatnich ludzi żyjących w bunkrze. Akt rebelii maszyny przeciwko swemu twórcy to niezwykle popularny temat utworów science fiction, jednak w Robocie motyw buntu zostaje odwrócony, ponieważ tu konstruktorem jest Mechanizm. Sprzeciwiając się mu, BER-66 staje po stronie rasy ludzkiej „wraz z licznymi jej zaletami i wadami” (Wiśniewski-Snerg 1977: 7) i tym samym dokonuje wyboru. Partricia Kerslake w Science Fiction and Empire zauważa, że Inny/Obcy, którego nie sposób odróżnić od Własnego, wzbudza największą trwogę (Kerslake 2007). W obecnej sytuacji jednak należy zadać pytanie, kto jest naprawdę Innym zagrażającym spójności i egzystencji Własnego? Bohater opowiada się po stronie człowieka, natomiast społeczeństwo zamieszkujące bunkier okazuje się przedłużeniem Mechanizmu. To, co na początku jawiło się jako część Własnego, teraz nosi znamiona Innego, tymczasem Inny/Obcy, czyli BER-66, zyskuje status Własnego.

Obraz relacji między Własnym a Innym wyłaniający się z Robota to opozycja oparta na dychotomii pary ludzkie-nie-ludzkie, przy czym ludzkie zachowania to takie, które charakteryzują się postawą humanistyczną, dążące do zachowania podmiotowości i indywidualności, natomiast nie-ludzkie kwestionują podmiotowość jednostki. Wnioski te możemy wysnuć, przyjrzawszy się nie-ludzkim robotom, zaledwie podszywającym się pod ludzi, jak i nie-ludzkim mieszkańcom 
powierzchni Kaula-Sud, zredukowanym do poziomu „zwierzęcych zwierząt” (Wolfe 2003: 110), służących wyłącznie jako zasób. Bycie człowiekiem nie jest więc z góry nam dane. Wręcz przeciwnie - człowieczeństwo w Robocie polega na aktywnym procesie ciągłego stawania się człowiekiem poprzez pielęgnację zachowań rozwijających lub podtrzymujących humanistyczną podmiotowość oraz jednoczesne ograniczenie zachowań skierowanych przeciw ludzkiej jednostkowości i niepowtarzalności. Nietrudno zauważyć, że jest to postawa wysoce antropocentryczna, jednak wyznacza ona niezwykle istotną rolę Innemu, tylko bowiem $\mathrm{w}$ rozpoznaniu i konfrontacji z Innym stajemy się Sobą.

Walter Benn Michaels zauważa, że uniwersum Orsona Scotta Carda również jest oparte na sporze między Innością a Swojskością, ale Mówca umartych podejmuje motyw Innego w odmienny sposób. Według Michaelsa konflikt między dwoma sportretowanymi w powieści rasami wynika z niemożliwych do pogodzenia różnic kulturowych, które - jak podkreśla - wydają się jedyną przepaścią niemożliwą do pokonania. Antagonizm ideologiczny nie jest uniwersalny i wieczny, gdyż światopogląd można zmienić. Jeśli z kolei spojrzymy na problem konfliktu między dwoma odmiennymi gatunkami z perspektywy etyki (w związku z czym dokonamy próby odczytania tekstu jako takiego, który w metaforyczny sposób wypowiada się na temat konfliktów międzyludzkich opartych na opozycji między Własnym i Innym), podkreślenie różnic fizjonomicznych między przedstawicielami tychże gatunków stanowi w zasadzie świadectwo tego, jak niewielką rolę te różnice odgrywają $\mathrm{w}$ obrębie jednego gatunku. Tymczasem od kultury, w której się wychowaliśmy i której część stanowimy, nie uciekniemy (Michaels 2000). W rezultacie konflikt między dwoma kulturami niezmiennie niesie za sobą niebezpieczeństwo wartościowania, a wtedy najczęściej spotkamy się z pokusą uprzywilejowania własnej kultury i próby podporządkowania oraz domestykacji kultury obcej.

Mówca umarlych skupia się na relacji ziemskich kolonistów planety Lusitanii a jej rdzennymi mieszkańcami, przezwanymi przez ludzi „prosiaczkami”. Relacja ta jest silnie nacechowana wiarą w prymat cywilizacji ludzkiej, która odrzuca kulturę prosiaczków zbudowaną na niezwykłych więziach z rdzenną florą i fauną planety. Monika Bakke, powołując się na obserwacje Charlesa Taylora, upatruje dwa rodzaje nie-ludzkiego: pochodzącego od boskości oraz pochodzącego z natury, "z której człowiek został wyodrębniony, a nawet wręcz wyizolowany i uznany za byt najdoskonalszy spośród innych form życia. To oznacza również wyparcie zwierzęcego elementu $z$ bytu ludzkiego i jednocześnie brak poszanowania dla świata zwierząt, roślin i innych form życia" (Bakke 2010: 23). Prosiaczki są postrzegane jako istoty niższe, bardziej prymitywne i niebezpieczne dla ludzi. Powodem tego jest brak zrozumienia ich cywilizacji oraz przekonanie, że Inne i Obce jest gorsze od tego, co znane i Swojskie.

Autor prezentuje nam sylwetki xenologów, którzy na Lusitanii pełnią funkcję podobną do antropologów bądź etnologów; ich zadaniem jest zgromadzenie wyczerpujących informacji na temat prosiaczków oraz zgłębienie ich kultury. Wiedza ta jest niezbędna do odpowiedzi na pytanie, czy prosiaczki przynależą do kategorii framling, czyli człowieka z innego świata, ramen - człowieka innego gatunku, czy może varlese - zwierzęcia, z którym nawiązanie prawdziwego kontaktu nie jest możliwe. Praca badawcza xenologów zostawia jednak wiele do 
życzenia. Skupiają się oni na wprowadzeniu ludzkich nowinek technicznych, które - jak wierzą bohaterowie - ułatwią życie małych mieszkańców lusitańskiego lasu. Ich ingerencja w rezultacie niemal kończy się katastrofą po tym, jak doprowadzają do zachwiania równowagi środowiska Lusitanii. Prosiaczki są w gruncie rzeczy skrytą rasą, zachłannie broniącą dostępu do swoich tajemnic, co nie ułatwia pracy badawczej. Niemniej jednak lusitańscy xenolodzy bardziej skupiają się na domestykacji obcości prosiaczków, aniżeli na próbach jej pojęcia bądź uszanowania. Przypomina to sytuację opisaną przez Cary'ego Wolfe'a w artykule Animal studies, dyscyplinarność $i$ (post)humanizm, w którym zwraca on uwagę na rolę społeczeństwa w neutralizacji Inności. Społeczeństwo obywatelskie wchłania jego pojedynczych, odmiennych członków, „spajając odmienne klasy i interesy poprzez uznanie, jakie otrzymują ich członkowie [...] postulując zespolenie tego, co wyjątkowe i tego, co uniwersalne, oraz globalny zasięg zachodniego pojęcia h e t e roge n icz ności" (Wolfe 2013: 131). Podobnie ziemscy bohaterowie powieści w geście dobrotliwej pobłażliwości, jaką liberalny humanizm często przyjmuje wobec strukturalnej Inności (Wolfe 2013), starają się włączyć odrębne kulturowo i gatunkowo prosiaczki do kręgu istot rozumnych, czyli ludzi. Tymczasem - jak wskazuje Waldefels - domestykacja Obcego jest w istocie jego unicestwieniem, ponieważ prowadzi do zmiany statusu Obcego z Innego na Egzotyczny (Waldenfels 2002). Nie chodzi już tylko o różnice anatomiczne, ale przede wszystkim kulturowe między cywilizacją ziemską a lusitańską; różnice, które xenolodzy uważają za niemożliwe do pogodzenia z cywilizacją ziemską.

Prosiaczki dokonują niezwykle okrutnego - w przekonaniu ziemskich badaczy - rytualnego mordu na dwóch osobach. Sceny zbrodni ukazujące zmasakrowane ciała xenologów, których prosiaczki musiały poddać wiwisekcji, zanim wyzionęli ducha, szokują, ponieważ stanowią realizację antropocentrycznego lęku przed Innym nie-ludzkim: 1) negatywne cechy ludzkiego podmiotu dotychczas tylko projektowane na zwierzęta ujawniają się w prosiaczkach oraz 2) ludzki podmiot zostaje w wyniku metodycznie (a nie brutalnie) przeprowadzonego zabiegu zredukowany do poziomu "zwierzęcego zwierzęcia” ${ }^{1}$. Motyw ten rozprawia się również z ideą przyjaznego czy wrogiego kosmity. Jak zauważa Gregory Benford, kategoria przyjaznego lub wrogiego partnera w stosunku do obcego jest z gruntu sprzeczna (Benford 1987). Przyjazne lub wrogie nastawienie są terminami odnoszącymi się wyłącznie do człowieka, więc próba przypisania prosiaczkom jednego $\mathrm{z}$ tych przymiotów jest kolejną odsłoną domestykacji obcych, a tym samym pozbawienia ich statusu Innego. Rozstrzygnięcie zagadki śmierci xenologów potwierdza ten postulat. Tajemnicze morderstwa dokonane na badaczach w rzeczywistości nie były zbrodniami z premedytacją, a rezultatem radykalnej różnicy między ludźmi i prosiaczkami. W wypadku prosiaczków rytualny mord jest $\mathrm{w}$ istocie ceremonią przejścia $\mathrm{z}$ tak zwanego drugiego do trzeciego życia. Po zręcznie dokonanej wiwisekcji ze zwłok prosiaczka wyrasta drzewo, które stanowi kolejną, w pełni świadomą siebie, formę bytu. Dla prosiaczka przejście do trzeciego życia jest najwyższym honorem i oznaką dojrzałości, ponieważ tylko $\mathrm{w}$ tej formie mogą one płodzić potomstwo. Mord popełniony na xenologach był zatem uhonorowaniem i próbą przyjęcia ich do swojego plemienia. Do zbrodni

${ }^{1}$ Szerzej o problemach antropocentryzmu wobec nie-ludzkiego pisze Monika Bakke (2010) $\mathrm{w}$ rozdziale Klopoty $z$ antropocentryzmem. 
by nie doszło, gdyby relacje między ludźmi i prosiaczkami przebiegały w partnerski sposób. Mając podstawową wiedzę na temat anatomii i fizjologii człowieka, prosiaczki nie dokonałyby zbrodni. Ich kontakty jednak miały inny charakter: było to jednostronne badanie obiektu przez podmiot, a jedyne próby zaszczepienia wiedzy zdobytej przez człowieka - jak wspomniałam wcześniej - wskutek ignorancji i poczucia wyższości badaczy nie przyniosły pozytywnych rezultatów.

Reakcja człowieka na Obcość wydaje się wysoce kłopotliwa. Z jednej strony jest ona nieodzowna dla Swojskości, ponieważ kształtuje ją. Z drugiej strony w obliczu Obcego człowiek za wszelka cenę stara się go zdomestykować, zredukować Inność do zaledwie Egzotyki. Niezachwiana wiara w antropocentryzm uniemożliwia tymczasem uznanie drogi innej niż ludzka; pozorne docenienie prosiaczków, próba włączenia ich do rodziny ludzkiej jako przedstawicieli klasy ramen (człowiek innego gatunku) to nic innego jak eliminacja różnicy. Pytanie, które wyłania się po lekturze Mówcy umarłych, według Michaelsa dotyczy przede wszystkim tego, czy dwie diametralnie różne kultury są w stanie koegzystować, nie skazując jednej z nich na zagładę (Michaels 2000).

Czy zatem kontakt z prawdziwie i radykalnie Innym i jego zrozumienie są wykonalne, czy też jesteśmy skazani na wieczne przeglądanie się w krzywym zwierciadle antropomorfizacji tego, co Obce, unicestwiając tym samym jego unikalną, nieprzeniknioną Obcość? Z odpowiedzią na to pytanie zmaga się Solaris Stanisława Lema. Powieść prezentuje postać obcego, który przekracza ludzkie możliwości zrozumienia do tego stopnia, że niemożliwe staje się nawet porozumienie z nim. Ocean Solaris jest inteligentnym organizmem badanym przez Ziemian od lat, jednak mimo wykształcenia dziedziny badawczej nazwanej "solarystyką", czyli wiedzy o Solaris, jest nieodgadniony, a wszelkie próby nawiązania znaczącego kontaktu pozostają bezowocne. Ocean Solaris stanowi ucieleśnienie obcości radykalnej.

Według Waldefelsa jednym z najtrudniejszych do rozwiązania problemów przy kontakcie z prawdziwie Innym jest asymetria w relacji Ja-Obcy:

Swoistą cechą tego, co obce, jest bowiem i to, że nie jest ono zsynchronizowane z własnym, a jeśli już, to w nader niezadowlającym stopniu. [...] obcość nie wyczerpuje się w tym, że istnieje coś, co przekracza naszą władzę dysponowania; raczej jest tak, że doświadczenie obcego wychodzi od obcego roszczenia, które uprzedza naszą własną inicjatywę. To, co należy powiedzieć i uczynić, nigdy nie pokrywa się z tym, co powiedzieć i uczynić można (Waldenfels 2002: 9).

„Jak pokazuje Lévinas, [brak synchronizacji - A.M.] nie polega [...] na tym, że role $\mathrm{w}$ dialogu przydzielane są w sposób jednostronny, lecz na tym, że roszczenie i odpowiedź nie są ze sobą zbieżne" (Waldenfels 2002: 131).

W Solaris przejawem tego są goście, których obecność czyni życie badaczy planety nieznośnym. Są to projekcje najskrytszych i najbardziej upokarzających win, a może też pragnień bohaterów. Dwójka z nich jest zażenowana swoimi gośćmi do tego stopnia, że nie pozwalają im ujawniać się reszcie załogi badawczej, a jednego z członków zespołu obecność gościa doprowadziła nawet do samobójstwa. Bohaterowie boją się konfrontacji z tym, co budzi w nich niesmak do samych siebie i rujnuje porządek ich wewnętrznego świata. Inaczej mówiąc, obawiają się konfrontacji z tym, co w nich samych jest Inne. Jak jednak rozumieć 
fakt, że wszelkie próby kontaktu z niewątpliwie inteligentnym bytem skutkują wyłącznie psychiczną torturą zadawaną bohaterom przez ocean? Powracamy tu do wspomnianego braku synchronizacji: to, co ludzie postrzegają jako mękę zadawaną im przez Solaris, dla samego oceanu prawdopodobnie jest czymś zupełnie innym. Badacze Lema, z profesorem Jerzym Jarzębskim na czele, upatrują $\mathrm{w}$ tym zjawisku krytykę antropocentryzmu i smutną konkluzję na temat możliwości poznawczych istoty ludzkiej (Jarzębski 2003). Aby zrozumieć intencję oceanu, badacze Solaris musieliby spojrzeć nań przez pryzmat badanej istoty, odrzuciwszy ludzkie rozumowanie oraz ludzką logikę. Krótko mówiąc, musieliby wyjść z samych siebie, co - jak dowodzi Istvan Csicsery-Ronay Jr. - jest niewykonalne, ponieważ „świadomość nie może uczynić przedmiotem obiektywnej obserwacji siebie samej" (Csicsery-Ronay Jr. 1989: 232). Obserwacja ta jest zgodna z postulatem Wolféa o próbie "odrzucenia jakiegokolwiek typowego pojęcia systemu [na rzecz - A.M.] dekonstrukcji własnego centralnego pojęcia" (Wolfe 2013: 136). W związku z tym świat przedstawiony Lema jawi się - jak określa to David Ketterer - jako gabinet luster, w którym człowiek jest w stanie tylko przyglądać się własnemu, zniekształconemu odbiciu (Csicsery-Ronay Jr. 1989). Powracamy tym samym do Husserlowskiego przeświadczenia o nieuchwytności Innego. Patrick Parrinder zauważa, że sama świadomość istnienia Tamtego nic nam nie daje bez kontaktu. Chociaż o pewnej jego formie możemy mówić, gdy weźmiemy pod uwagę Harey: wspólny twór Solaris i Kelvina, to jednak nie możemy dostrzec niczego wykraczającego poza ramy projekcji ludzkiej świadomości (Csicsery-Ronay Jr. 1989). Podczas próby obiektywnego zbadania czy też zrozumienia nie tylko Innego, ale i Własnego, antropocentryzm wyłania się ponownie jako narzędzie wysoce wadliwe.

Zauważmy, że we wszystkich przytoczonych utworach podstawową reakcją na Inność jest ciekawość motywująca bohaterów do zgłębienia tajemnicy ukrytej w niedostępnej Własnemu przestrzeni i następujące po niej przerażenie Innością. Kolejna pojawia się wrogość bądź próba domestykacji Inności, przy czym warto zwrócić uwagę, że obie reakcje są próbą rozbrojenia Innego poprzez eliminację (dosłownie lub za pomocą włączenia Inności w domenę Swojskości). Wina za taki stan rzeczy spoczywa na antropocentryzmie wpisanym w myśl humanistyczną. Warto przypomnieć, że w wypadku BERa-66 bunt przeciwko opresyjnemu Mechanizmowi stanowi o jego człowieczeństwie i dzięki temu może być odczytany niemalże jako manifest humanisty w obliczu groźby utracenia człowieczeństwa w ponowoczesnej rzeczywistości. BER-66 niczym Bernard Rieux w Dżumie poszukuje szansy ocalenia człowieczeństwa w obliczu nieuchronnej katastrofy, anihilacji człowieka w Kaula-Sud. Co znamienne, główny bohater Robota nie pochodzi przecież z gatunku ludzkiego, mimo idealnej kopii fizjonomii i psychiki ludzkiej jest tylko robotem. Jak wspomniałam wcześniej, jest to wyraz przeświadczenia o tym, że człowiekiem się nie jest, ale się nim staje. Reakcja na Inność przedstawiona zarówno w Mówcy umartych, jak i Solaris nie jest już tak jednoznaczna. Oba utwory zarzucają antropocentryzmowi nieporadność w próbach pojęcia nie tylko Inności, ale też Swojskości, upatrując przyczyny porażki poznania Innego i Własnego w braku możliwości oraz (co ważniejsze) w braku chęci odrzucenia ludzkiej perspektywy. Problem ten, szczególnie widoczny w Solaris, dotyczy też świata przedstawionego Mówcy umarlych. W końcu xenolodzy 
zajmujący się prosiaczkami próbują zgłębić tę obcą rasę, odnosząc się tylko do siebie samych, natomiast $\mathrm{w}$ oderwaniu od naturalnego środowiska lusitańskiego, błędnie zinterpretowanego jako identyczne z ziemskim wyłącznie na podstawie powierzchownego podobieństwa między dwiema biosferami. W wypadku Solaris sam fakt bycia człowiekiem, posiadania ludzkiej psychiki, a przez to i podświadomości, stanowi barierę nie do pokonania. Prowadzi to do smutnej konkluzji, że dialog między Własnym a Innym nie jest możliwy, dopóki człowiek kieruje się antropocentrycznym przeświadczeniem o prymacie bytu ludzkiego nad każdym innym. Potrzeba nam decentralizacji, a raczej rozszerzenia podmiotu humanistycznego tak, by obejmował również nie-ludzką Inność. Wydaje się, że rozwój myśli posthumanistycznej daje szansę podmiotowego ujęcia Innego, ponieważ właśnie posthumanizm postuluje odejście od koncepcji „człowieka osamotnionego i tym samym zubożonego, gdyż zredukowanego wyłącznie do samego siebie” (Bakke 2010: 87). Istota ludzka nie stanowi ostatecznego celu czy finalnego wyniku ewolucji, ale jest kolejną jej fazą. Stąd bycie ludzkim może nie mieć nic wspólnego z przynależnością do gatunku ludzkiego (Hollinger 2009). Finał Mówcy umartych również sugeruje to rozwiązanie: szczęśliwe zakończenie jest możliwe dopiero wówczas, gdy ziemscy koloniści na Lusitanii, doceniwszy Inność skolonizowanej planety, zaczynają postrzegać siebie jako element lusitańskiego krajobrazu, nie zaś jego architektów, a w rezultacie zrywają wszelkie relacje z Ziemią.

\section{Literatura:}

Bakke M., 2010, Bio-transfiguracje. Sztuka i estetyka posthumanizmu, Poznań: Wydawnictwo Naukowe Uniwersytetu im. Adama Mickiewicza.

Benford G., 1987, Effing the Ineffable [w:] Aliens: The Anthropology of Science Fiction, eds. G.E. Slusser, E.S. Rabkin, Carbondale: Southern Illinois University Press.

Csicsery-Ronay I. Jr., 1989, Książka jest Obcym: o pewnych i niepewnych interpretacjach Solaris Stanistawa Lema, tłum. T. Rachwał [w:] Lem w oczach krytyki światowej, wyb., oprac. J. Jarzębski, Kraków: Wydawnictwo Literackie.

Hollinger V., 2009, Posthumanism and Cyborg Theory [w:] The Routledge Companion to Science Fiction, eds. M. Bould, A.M. Butler, A. Roberts, S. Vint, London-New York: Routledge.

Jarzębski J., 2003, Przygody Rycerzy św. Kontaktu [w:] idem, Wszechświat Lema, Kraków: Wydawnictwo Literackie.

Kerslake P., 2007, Science Fiction and Empire, Liverpool: Liverpool University Press.

Lehan R., 1998, The City in Literature: An Intellectual and Cultural History, Berkeley: University of California Press.

Michaels W.B., 2000, Political Science Fictions, „New Literary History” No. 4.

Nawrocki R., 2011, Literatura, nauka, herezja, Snerg, Gdańsk: Gdański Klub Fantastyki.

Waldenfels B., 2002, Topografia obcego: studia z fenomenologii obcego, tłum. J. Sidorek, Warszawa: Oficyna Naukowa.

Wiśniewski-Snerg A., 1977, Robot, Kraków: Wydawnictwo Literackie.

Wolfe C., 2003, Animal Rites. American Culture, the Discurse of Species, and Postumanist Theory, Chicago: University of Chicago Press.

Wolfe C., 2013, Animal studies, dyscyplinarność $i$ (post)humanizm, tłum. K. Krasuska, „Teksty Drugie" nr $1 / 2$. 


\begin{abstract}
Abstrakt
W artykule przedstawiam, w jaki sposób literatura science fiction, wykorzystując cechy Innego oraz zależność między Innym i Własnym, kreuje postać kosmity. Pokazuję, jak tego rodzaju literatura wykorzystuje obcego, aby mówić o problemach związanych z definicją człowieczeństwa, reakcją na to, co Inne, oraz kwestią możliwości zrozumienia Innego. Zagadnienia te omówię, posługując się trzema przykładami kreacji obcego: w Robocie Adama Wiśniewskiego-Snerga, Mówcy umartych Orsona Scotta Carda i Solaris Stanisława Lema.
\end{abstract}

\title{
Słowa kluczowe
}

obcy, Inny, Własny, związek

\section{Summary}

The Alien as the Other: Various Images of the Alien in Science Fiction Literature

The Other simultaneusly terrifies and fascinates; the Other crosses boundaries which the Self would never dare to cross or, in some cases, would not even be able to recognize. Finally, the Other resides also within the Self. Drawing inspiration from this unique relationship between the Other and the Self, science fiction literature ascribes the qualities of the Other to alien characters. In this article, I will attempt to demonstrate how alien characters are employed in science fiction in order to discuss ontological questions of defining what humanity is, ethical questions regarding the reception of the Other, and epistemological ones regarding the human capability of comprehending the Other. I will support my line of argument with examples of the depiction of alien characters from Robot (1973) by Adam Wiśniewski-Snerg, Speaker for the Dead (1986) by Orson Scott Card, and Solaris (1961) by Stanisław Lem as well as their functions.

\section{Keywords}

alien, Other, Self, relationship 
